\title{
Knowledge Workers Job Performance: An Examination of Career Values, Perceived Organizational Support and Career Satisfaction
}

\author{
Muhammad Awais Bhatti \\ College of Business, King Faisal Univesity, Al-hufuf, Al-hassa, Saudi Arabia \\ E-mail: awaisbhatti_786@yahoo.com \\ Ariff Syah Juhari \\ College of Business Administration, Prince Sultan University, Saudi Arabia \\ E-mail: asyah@psu.edu.sa
}

\begin{abstract}
Shishi Kumar Piaralal
Faculty of Business Management for Open University Malaysia, Kuala Lumpur, Malaysia

E-mail: shishi@oum.edu.my

Niriender Kumar Piaralal

Operation Management, Raj Dulari Enterprise, No. 5 Pekan Mahang, Kedah, Malaysia

E-mail: shanni1624@yahoo.com
\end{abstract}

Received: Nov. 2, 2017 Accepted: Nov. 8, $2017 \quad$ Published: Nov. 13, 2017

doi:10.5296/bmh.v5i2.12138 URL: http://dx.doi.org/10.5296/bmh.v5i2.12138

\begin{abstract}
Knowledge workers help organizations improve productivity and gain competitive advantage in the market. Since organizations have realized the importance of knowledge workers in organizational development, management has been focusing on the knowledge workers' job performance, which ultimately improves the organizational performance. The purpose of this study is to investigate the mediating effects of the knowledge workers' career satisfaction
\end{abstract}




\section{Macrothink}

among career values, perceived organizational support and job performance. In this regard, data was collected from 284 knowledge workers working in Saudi Arabian organizations and it was analyzed using regression and Sobel test. The result of the analysis explain that career satisfaction play a key role in knowledge workers' job performance, and work as mediator between career values, perceived organizational support and the knowledge workers' job performance. The findings of this study will be helpful for top management and HR professionals to manage the knowledge workers' job performance. Furthermore, the mediating role of career satisfaction contribute to the body of knowledge and offer future researchers opportunities to investigate other factors, which influence career satisfaction of knowledge workers. This study also discussed some limitations which could be an avenue for future research. Research on Saudi Arabian knowledge workers has never been done before. Therefore, this study explores the effects of career values, perceived organizational support and career satisfaction on Saudi Arabian knowledge workers' job performance.

Keywords: Knowledge workers, Career satisfaction, POS, Career values, Saudi Arabian Knowledge workers 


\section{Introduction}

In the 21st century, organizations have been searching for new knowledge to achieve competitive advantage in the current market and for smooth growth. Workers who carry out these tasks, known as knowledge workers, require specialized techniques, specific knowledge, undertake thinking, visible productivity and efficiency and ideas towards solving complex and specific problems (Fisher \& Fisher, 1998). Knowledge workers play an important role in the organizational growth and economic development. In past research, many researchers have highlighted the characteristics and personality traits of knowledge workers, which play an effective role in organizational and economic growth. Knowledge workers (KWs) play a vital role in economic development (Yigitcanlar et al., 2007) and help organizations achieve competitive advantage in the market (O’Neill \& Adya, 2007).

Past researchers have paid sufficient attention in highlighting factors that attract knowledge workers. It has been reported that good remuneration might play an important role in attracting knowledge workers but it has not helped organizations retain them for a longer period of time (Horwitz et al., 2003). In this regard, Lock (2003) reported that opportunities for career advancement play an important role for the knowledge workers' motivation, which can be done by offering traditional training programs. Wayne et al. (1997) argued that when employees realized that their work and efforts for organizations have been appreciated, they try to improve their job performance and participate more actively in forming organizational behavior. Expectancy theory (Vroom, 1964) as stated by Wayne et al. (1997) explained that when individuals realized that they can achieve whatever they want by doing certain work, they feel more motivated to do that work. In addition, expectancy theory also explains that individuals performed certain action based on their perception and beliefs, which can be categorize in three different types. Firstly, the belief that their efforts can help them to achieve desired goals. Secondly, expecting some rewards against their effort as outcome, and thirdly, the value of achieving the outcome. Mohammad et al. (2008) argued that success and failure of knowledge workers are based on their belief and attitude about knowledge sharing. They further suggest that knowledge workers' motivators might prompt them to engage in knowledge sharing activities.

\section{Literature Review}

The concept of job performance and career satisfaction are still debatable topics for researchers, as well as policy makers. Hassan (2007) examined the role of conflict, ambiguity, personality traits, vocational choices, career decision and more on career satisfaction to find out what are the major factors which effect job performance. Recently, researchers have paid more attention on knowledge workers' job performance (Belinda, 2007; Chen, 2010; Chen, 2011). In the last two or so decades, researchers have placed attention towards finding out the influence of knowledge worker's job performance on career satisfaction (Belinda, 2007; Chen 2010; Chen 2011); few researches have been about the relationship and impact of other variables like POS, demographics and human capital factors on job performance and career satisfaction. In this regard, (Chen, 2010; Chen, 2011) have examined the relationship between the knowledge employees' career satisfaction, job performance, perceived organizational 
support and career values.

The aim of this research is to investigate the influences and contributions of career satisfaction, career values, perceived organizational support and on job performance. Satisfaction of knowledge workers, which lead to career satisfaction is not only a problem or issue for employees alone; it has also been the main influence in the success of the employer itself. Poole et al. (1991) stated that, with a course of time, if knowledge workers feel dissatisfaction and organizations struggle to keep a hold of their knowledge employees, it will negatively affect the commitment between knowledge workers and organizations, and finally will effect the goals of the organization. Moreover, it is important (Gattiker \& Larwood 1990) to find out the effects of career values, perceived organizational support, and career satisfaction on knowledge workers job performance. Generally every knowledge worker wants to join any organization where he or she acquire basic rights like feel comfortable within his or her work environment, have the same authority and power, mentally, materially and physically satisfied, be contented with his or her overall achievement (Podsakoff et al., 2007; Judge et al., 1995; Barling, 2001). Career satisfaction and job performance is a tool to analyze and quantify the power, potential and achievement of the individual knowledge worker, which is helpful for managers in an organization. It is also helpful to know the needs of knowledge workers, that is, what an individual knowledge worker actually wants from work. In other words, an individual job need might have a strong influence on job satisfaction.

\subsection{Career Satisfaction}

Arthur et al. (2005) argued that an employee's career satisfaction is a result of the employee's career experience. In conventional point of views, career satisfaction is considered equal to salary increment, career advancement, and promotion (Sullivan et al., 1998). However, over the course of time, the employee's perception about career has changed, and that the employee perceived career satisfaction in two different ways. Heslin (2005) explained that the employees' perceived career satisfaction are in terms of extrinsic career satisfaction and intrinsic career satisfaction. Extrinsic career satisfaction refers to salary increments, promotion or financial rewards, whereas intrinsic career satisfaction refers to appreciation, encouragement or psychological satisfaction (Gunz \& Heslin, 2005). There is no doubt that the employee's career satisfaction is the result of the employee's career experience. Therefore, researchers defined career satisfaction as an achievement of targeted work-related objectives at any point of the employee's work experience. In this regard, Oxford English Dictionary (1989) explained two meanings of satisfaction as achievement of objective as per the individual desire and progressive accomplishment of something targeted.

Juntunen et al. (2001) conducted qualitative research to find out the meaning of employee career satisfaction and found that employee career satisfaction was measured by past researchers based on their contribution to the well-being of others. Heslin (2005) commented on these findings and argued that the qualitative research helped the researchers to highlight the largely neglected facets of career satisfaction. In addition, Hannequin (2007) followed Heslin's (2005) suggestions and conducted another qualitative research in order to know the 
career satisfaction of blue-collar workers. Hannequin (2007) found out that material satisfaction (financial rewards, promotion, and incentives), psychological career satisfaction (career satisfaction, job satisfaction, personal satisfaction and work-life balance) and social career satisfaction (fame, and appreciation) are the main factors that satisfied blue-collar workers. Whatever the perception of career satisfaction, what remains certain is that there are several variables that could be used in the measurement of career satisfaction. While some researchers use quantitative methods, others rely on qualitative research to investigate career satisfaction. However, this research is a quantitative one and relies on two variables: career values and POS, out of many others, to measure career satisfaction, while considering the objective or extrinsic and subjective or intrinsic nature of career satisfaction.

\subsection{Career Values and Career Satisfaction}

Shapira \& Griffith (1990) argued that, in the last four decades, researchers have been focusing on investigating the effects of work values on the employee's behavior and attitude. In the past, many researchers have also investigated the role of intrinsic and extrinsic rewards, work values in relationships with work commitment and job satisfaction (Wong \& Chung, 2003). In order to understand the meaning of work values, it is important to understand the meaning of values. In this regard, the noted researcher of values and the value system (Rokeach, 1973) define values as "an enduring belief". This definition explains that values and the value system are somewhat related thoughts. For example, values refer to preference for behavior and the value system refers to the importance of values given to others in the system. There are different types of social relationships in which an individual create values, and the workplace is one of the major social environments in which individuals create, share and develop values. In this regard, Roe \& Ester (1999) argued that values and work differentiate the general values with values related to specific life domains. Therefore, this differentiation is universally accepted but researchers have a lack of consensus between these two types of values. One pool of researchers argued that work values is a subset of general values, whereas another pool of researchers argue that "taking a more holistic view integrating work and non-work values, may be more productive" (Elizur \& Sagie, 1999) by focusing on the structural similarity between work values and general values.

Researchers argued that employee's values affect their behavior and attitudes (Peter \& Olson, 2001). Work values explain the individual's preferences and beliefs which they expect to satisfy in their career choices (White, 2005). In this regard, Sagie et al. (1996) argued that individual preferences and belief for the satisfaction of their career choice create work values which influence their job behavior. Researchers argued that values are different from needs, and that work values explains what an employee want from work. Therefore, researchers defined work values as the importance in which an employee gives to outcome from work context (Elizur, 1984). In addition, employee's job needs strongly influence employee's job satisfaction. Therefore, when employees job needs get satisfied, their job satisfaction also get increase regardless how that employee value his/her rewards. Therefore, the researcher hypothesizes:

H1: Career values are positively related to knowledge workers career satisfaction. 


\subsection{Perceived Organizational Support (POS) and Career Satisfaction}

Past researches have suggested that organizational-level factors should be considered when examining the effects on career satisfaction. This study tries to establish that perceived organizational support relates to the knowledge employees' career satisfaction. Eisenberger et al. (1986) introduced the concept of Perceive Organizational Support (POS) in order to explain employee's perception towards organization's commitment. Rhoades \& Eisenberger (2002) argued that leaders in the organization should take serious initiatives to discuss the policies and programs for organizational support in order to encourage organizational support at an acceptable level. In addition, organizations need to realize that organizational support should be beyond the boundaries of the workplace in order to facilitate the employees' general and interaction adjustment which will further improve the employees' commitment towards the organization (Aube', Rousseau, \& Morin, 2007; Gupta, Vohra, \& Bhatnagar, 2010). Therefore, it can be concluded that the employee's adjustment is not only based on the work environment but also adjustment in the organizational culture.

Literature related to perceived organizational support highlighted that the concept influences employees work stress, job performance, job satisfaction and affective commitment (Hochwarter et al., 2003). In this regard, Seibert et al. (1999) reported that if employees perceived that the organization care about their values and appreciate their contribution for the organization, their commitment towards the organization would then increase. Furthermore, Chen \& Fang (2008) found that when employees realize that organizational politics is at low level, performance improves. Riggle et al. (2009) argued that managers can use "social exchange views" to explain the importance of commitment between employees and employer. In this regard, Riggle et al. (2009) investigated the effects of perceived organizational support job satisfaction, organizational commitment, employee's performance and employee's intention to leave. The results of this investigations indicated that the employee's job satisfaction strongly influence perceived organizational support. Furthermore, DeConinck (2010) investigated the mediating role of perceived support between organizational justice and trust. The findings of this investigation indicated that perceived organizational support mediate the relationship between procedural justice and organizational trust.

Similarly, an employee whose perceived organizational support is high believe that the organization appreciates their effort and their contribution for the organization. The reason behind this belief is that employees with greater perceived organizational support are more committed and attached with the organization, as compared to those with low level of perceived organizational support. Furthermore, in comparison with employees having a low level of perceived organizational support, employees with a high level of perceived organizational support have a stronger belief that their efforts will convert to rewards. In addition, researchers found that perceived organizational support positively influence the supervisor and subordinate relationship (Wayne et al., 2002) and POS "appears to be an important source of esteem, affiliation, emotional support, and approval in the workplace" (Armeli et al., 1998). Therefore, all these factors help employees to improve his/her job performance, which further lead to employee satisfaction (Dulac et al., 2008) and Tekleab et 
al., 2005).

Rhoades \& Eisenberger (2002) found that perceived organizational support positively influence organizational commitment and employee's job satisfaction. Therefore, it can be concluded that perceived organizational support is connected with employee's job satisfaction as well. Rhoades \& Eisenberger (2002) found that perceived organizational support positively influence promotion, pay, and recognition. In this regard, Noe (1996) argued that supportive supervisor or management influence the employee's willingness to participate in development activities, which further play an important role in the subordinates' performance and career satisfaction. Moreover, Kirch-meyer (1998) found that supervisor support positively influences the male and female managers' perceived career satisfaction. In addition, Greenhaus et al. (1990) reported that supervisor support positively influence employees' career satisfaction. Barnett et al. (2007) examined the relationship between organizational support for career development and employees' career satisfaction, and reported that career management behaviors mediate the relationship between proactive personality and career satisfaction, and the organizational support for career development and career satisfaction. Based on the different relationships discussed in the above paragraphs, it can be concluded that perceived organizational support in the form of traditional training programs, mentorship, and supportive work relationship enhance career opportunities and maximize career satisfaction. Therefore, if perceived organizational support help the organizations to gain some benefits in terms of the employee's career satisfaction, then the organization should focus and try to provide maximum support to the employees. It is acceptable that it is not possible for all organizations to provide maximum support to the employees but these things can be covered up by increasing work autonomy. In this regard, Aube et al. (2007) argued that organizations can improve recruitment process in order to make sure employees with a high level of control should be hired because these employees will be more capable of maintaining their commitment with the organization. Therefore, this research proposed that perceived organizational support positively influence the knowledge worker's career satisfaction. Based on the discussion above, a hypothesis is developed.

H2: Perceived Organizational Support positively related with knowledge workers Career Satisfaction.

\subsection{Career Satisfaction and Job Performance}

In this study, job performance is the dependent variable, which is one of the frequently used variables in the organizational psychology. IIgen \& Klein (1988) stated that, researchers need to understand the factors that affect motivation. This understanding help managers develop the conditions in the work place where knowledge workers encourage personal behavior. Job performance is a multi-dimensional approach and there is a major issue on how to conceptualize this term, for example, Suliman (2001) explained the six dimensions of job performance, namely work duties, work skills, quality of work, work enthusiasm, quantity of work and innovative potential.

Furthermore, Farth et al. (1991), defined job performance in the form of quality and quantity, while Yousef (1998) capture performance in terms of productivity of performance and quality. 
Moreover, Borman \& Motowidlo (1997) differentiate job performance into task and contextual performance. Task performance directly refers to quantity of goods and services produced, while the behavior of contextual performance is not directly related to their main task (Werner, 2000). For example, when knowledge workers cooperate with managers, helps each other or make positive suggestions and comments about organizational processes, employees engage in contextual performance Van Scotter et al. (2000) discuss about the knowledge worker' career satisfaction and job performance, the process and the theory of social exchange, linking the former to the latter construct. Vroom (1964) coded the expectancy theory and argued that a knowledge worker's job performance is determined by the available degree to attractive reward, so higher the degree of attractive reward leads to a higher level of performance.

For the purpose of efficient production or to achieve the ultimate goal of an organization, it is very important to analyze the job performance of a knowledge worker. By knowing the job performance, we are able to calculate the marginal cost of production and minimize the cost or increase production to maximize the profit. Keep importance of job performance in front, researchers try to find out important factors which affect job performance. Osman (2012), stated that the most important factor which affects the service recovery performance and job performance is career satisfaction. In today's competitive market environment, a top priority for a firm is to deliver quality products, and job performance of a knowledge worker play a key role in this process (Bouranta et al., 2009; Yavas et al., 2010). Career satisfaction can play a mediating role between perceived organizational support, career values and job performance (Muse \& Stamper, 2007). Based on the theory of social exchange, knowledge workers tend to repay opportunities and benefits given by the organization in the shape of continued effective performance (Armstrong-Stassen \& Ursel, 2009) As the knowledge worker gain organizational support, he or she becomes satisfied with their career and improve in their job performance (Greenhaus et al., 1990; Kong et al., 2012; Parasuraman et al., 1996). There are many empirical studies that found significant relationship between perceived organizational support and employee outcome, such as job performance, turnover intention, organizational commitment (Rhoades \& Eisenberger, 2002; Susskind et al., 2000). Researchers found that, the lack of formal training in the firms and organization leads to poor job performance and ultimately, poor service quality and delivery (Kimbu, 2011).

In another case, if knowledge workers perceive that the management of the organization do not give any support, they would appear to view their jobs as a dissatisfaction (Susskind et al., 2000). According to the theory of social exchange, knowledge workers tend to repay this displeasing in the form of ineffective performance.

In empirical terms, Cable \& Derue (2002) found significant and positive association between perceived organization support and career satisfaction. In addition, a recent empirical study found that perceived organizational support enhanced employee's satisfaction with their career (Armstrong-Stassen \& Ursel, 2009). Such type of finding showing a correlation between the two variables is not trivial. The same researcher investigated the influence of a certain level of stress on job performance. Yerkes \& Dodson (1982) found that a U-shaped function between job performance and stress; they suggested that moderate level of stress can 


\section{Al Macrothink}

Business and Management Horizons

ISSN 2326-0297

2017, Vol. 5, No. 2

motivate for better performance, while too little or too much stress give insignificant motivation to the performer. In addition, Allen et al. (1982) differentiate stress into two parts: dysfunctional stress and functional stress, while in an organization, dysfunctional stress is more dominant as compare to functional stress. Most probably, the knowledge worker facing stress in an organization is more likely to be dysfunctional stress than it has negative effect on his job performance. Jamal \& Baba (1992) investigated the effects of stress on productivity, based on four different stress factors: overload, ambiguity, conflict and adequacy of resources; they concluded that, as much greater the stress, the less the knowledge worker's job performance, and that less work stress leads to greater job performance.

H3: career satisfaction positively related with knowledge workers Job performance.

H4: Career Satisfaction mediates the relationship between career values and knowledge workers job performance.

H5: Career Satisfaction mediates the relationship between perceived organizational support and knowledge workers job performance.

The real objective of this study is to ascertain the levels and the relationship of career values and perceived organizational support with career satisfaction, which further leads to knowledge worker job performance. The research framework is aimed at determining the significant factors affecting career satisfaction which can be addressed by management in formulating effective and efficient policies and strategies in order to maximize the policies designed to help knowledge employees succeed.

Independent Variable

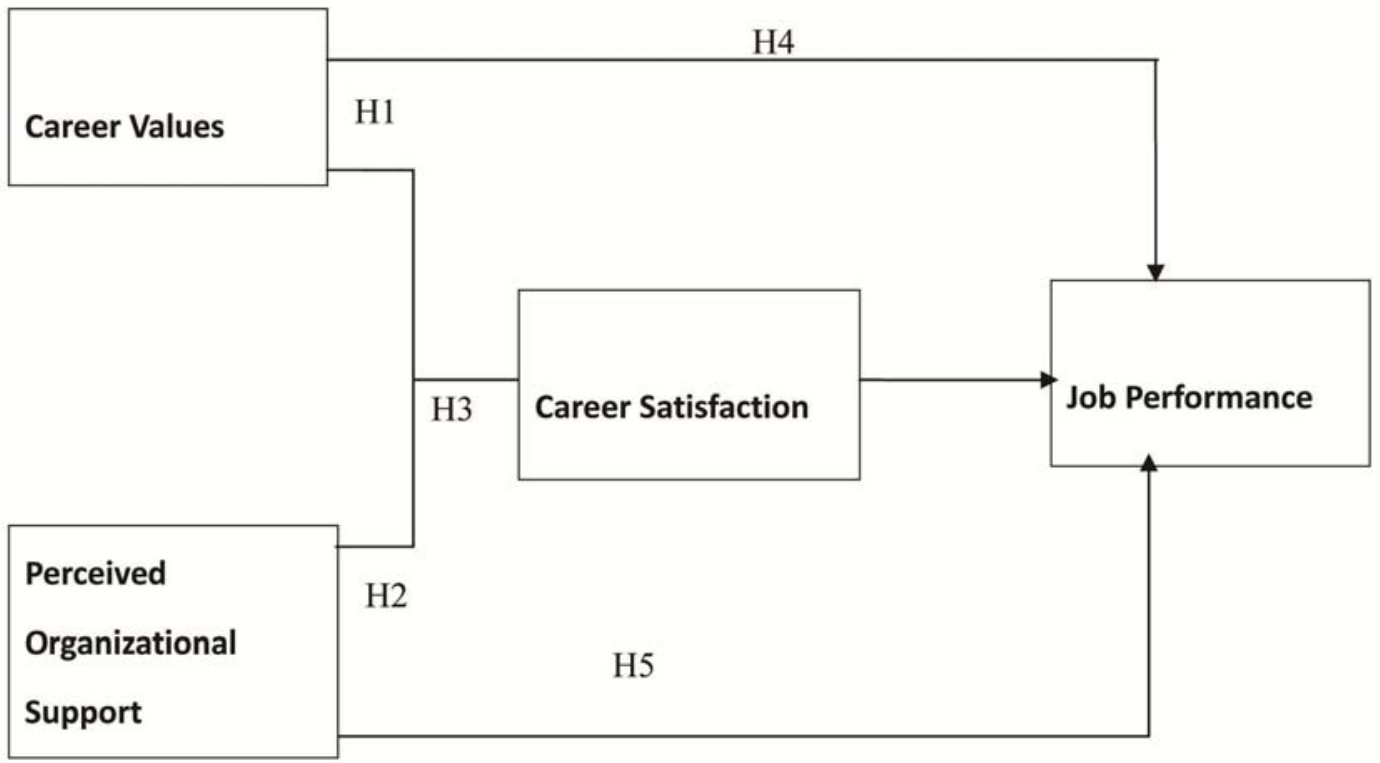

Figure 1. Conceptual framework 
3. Methodology

This study focuses on identifying the effects of career values and perceived organizational support on knowledge workers career satisfaction and job performance. Therefore, employees in different Saudi Arabian organizations, government Universities and hospitals were surveyed as the unit of analysis.

\subsection{Measurements}

A survey was prepared to incorporate the five instruments used for this study. The questionnaire was divided into five parts. Career values instruments was covered on part A. The scale to measure career values was adopted from (Chan, 2011) with fifteen items. The second part covered instruments on perceived organizational support. In order to measure perceived organizational support, a sixteen-item scale was used which was developed by Rhoades \& Eisenberger (2002). Part C consisted of five items to measure career satisfaction developed by Judge et al. (1999). Part D consisted of seven items to measure job performance developed by Babin \& Boles (1998) and the final part focused on demographic details, which included information regarding gender, nationality, age, marital status, tenure, position, whether or not they had accompanying family and whether or not they are holding Saudi Arabian Permanent Resident status. For sections A, B, C, and D, the respondents were required to respond based on a 5-point Likert scale from strongly agree $=5$ to strongly disagree $=1$. The questionnaire was conducted in its original English format, since the subjects have been predetermined to have good command of English.

\subsection{Data Analysis}

In this research, the researcher used the Statistical Package for the Social Science (SPSS) Version 19 to analyze the data collected from the respondents. All of the items and variables in the questionnaire were coded before it was distributed to the respondents. Several statistical methods were used in data analysis. The collected data were tested by using statistical techniques as followed frequency distribution, descriptive statistics, and regression analysis.

Frequency distribution was collected from all of the personal data (Classification variable). The collected frequencies were computed for the analysis of the respondent's demographic factors of gender, age, marital status, education. The hypothesis testing was analyzed with regression analysis with Cronbach's Alpha values 0.60 and above. The item with low Cronbach's Alpha values of less than 0.59 were excluded from further analysis process.

\subsubsection{Demographic Profile of Respondents}


Table 1. Respondent profile

\begin{tabular}{|l|l|l|}
\hline Respondent Characteristics & Frequency & Percentage (\%) \\
\hline Gender & & \\
Male & 164 & 57.7 \\
Female & 120 & 42.3 \\
Age & 45 & \\
31-41 years old & 125 & 15.8 \\
42-51 years old & 90 & 44.0 \\
52-61 years old & 24 & 31.6 \\
62 \& above & & 8.4 \\
Program of study & 14 & \\
Diploma/Certificate & 56 & 4.9 \\
Bachelor Degree & 39 & 19.7 \\
Masters & 131 & 17.2 \\
Doctorate & 34 & 46.1 \\
Other & & 11.9 \\
Marital Status & 54 & \\
Single & 216 & 19.0 \\
Married & 14 & 76.0 \\
Divorced/Widowed & & \\
Years Employed & 39 & 13.7 \\
Less than 4 year & 91 & 32.0 \\
5-7 years & 70 & 24.6 \\
8-11 years & 84 & 29.5 \\
11 and above &
\end{tabular}

Table 2. Reliability analysis

\begin{tabular}{|l|l|l|}
\hline Variable & Number of Items & Alpha \\
\hline Career values & $\mathbf{1 5}$ & $\mathbf{0 . 8 6}$ \\
Perceived Organizational Support & $\mathbf{1 6}$ & $\mathbf{0 . 8 5}$ \\
Career satisfaction & $\mathbf{0 8}$ & $\mathbf{0 . 9 2}$ \\
Job Performance & $\mathbf{0 7}$ & $\mathbf{0 . 7 1}$ \\
\hline
\end{tabular}

The above Table 2 shows that the reliability coefficient of all variable is higher than the minimum acceptance level of 0.60 , as suggested by Hair et al. (2013). As indicated in the above table, Cronbach's Alpha of career values is 0.86 , Perceived organizational support is 0.85 , career satisfaction 0.92 and job performance is 0.71 , which indicate that the scales are reliable.

Table 3. Descriptive analysis

\begin{tabular}{|l|l|l|l|l|}
\hline Variables & Mean & S.D & Skewness & Kurtosis \\
\hline Career Values & 35.73 & 5.603 & 0.075 & -0.441 \\
\hline Career Satisfactions & 38.30 & 6.704 & -.153 & -.806 \\
\hline Perceived Organizational Support & 19.24 & 5.328 & -.336 & -.407 \\
\hline Job Performance & 10.20 & 2.171 & -.204 & -.529 \\
\hline
\end{tabular}


Table 3 represents the skewness and kurtosis values. All values fall within the range of $(+)(-)$ 2.58 as suggested by Hair et al. (2006). The skewness and kurtosis values should be within the range of $(+)(-) 2.58$ which shows that the data is normally distributed.

Table 4. Effects of career values, perceived organizational support on career satisfaction

\begin{tabular}{|c|c|c|c|c|c|c|c|}
\hline & \multicolumn{7}{|c|}{ Coefficients $^{\mathrm{a}}$} \\
\hline \multirow[t]{2}{*}{ Model } & \multicolumn{4}{|c|}{ Unstandardized Coefficients } & \multicolumn{3}{|c|}{ Standardized Coefficients } \\
\hline & $\mathrm{R}$ & R Square & B & Std. Error & Beta & $\mathrm{t}$ & Sig. \\
\hline \begin{tabular}{l|l}
1 & (Constant) \\
\end{tabular} & 0.510 & 0.260 & 2.170 & 0.289 & & 7.498 & .021 \\
\hline Career Values & & & .924 & .325 & .310 & 2.845 & .006 \\
\hline $\begin{array}{l}\text { Perceived } \\
\text { Organizational } \\
\text { support }\end{array}$ & & & .796 & 208 & .348 & 3.822 & .000 \\
\hline
\end{tabular}

Table 4 shows the effects of career values and perceived organizational support on career satisfaction. The results of the regression analysis indicates that career values $(p=.006)$ and perceived organizational support $(\mathrm{p}=.000)$ influence knowledge workers career satisfaction. Hair et al. (2007) suggested that $\mathrm{p}$ value should be less than $0.05(\mathrm{P}<0.05)$. Furthermore, the results of the regression analysis explain that career values and organizational support explained $26 \%(\mathrm{R}$ square $=0.26)$ of the variance in knowledge workers career satisfaction. Finally, the results of the regression analysis also indicate that between two independent variable (career values and POS), where career values have a stronger effect on career satisfaction, as compared to perceived organizational support.

Table 5. Effects of career satisfaction on knowledge workers' job performance

\begin{tabular}{|c|c|c|c|c|c|c|c|c|}
\hline \multirow{4}{*}{\multicolumn{2}{|c|}{ Model }} & \multicolumn{7}{|c|}{ Coefficients $^{\mathrm{a}}$} \\
\hline & & \multirow{2}{*}{\multicolumn{4}{|c|}{ Unstandardized Coefficients }} & \multicolumn{3}{|c|}{ Standardized Coefficients } \\
\hline & & & & & & \multirow{3}{*}{ Beta } & \multirow[t]{2}{*}{$\mathrm{t}$} & \multirow[t]{2}{*}{ Sig. } \\
\hline & & $\mathrm{R}$ & R Square & $\mathrm{B}$ & Std. Error & & & \\
\hline \multirow[t]{2}{*}{1} & (Constant) & 0.610 & 0.372 & 1.745 & 0.282 & & 6.189 & 0.000 \\
\hline & Career Satisfaction & & & .526 & .073 & .610 & 7.225 & .000 \\
\hline \multicolumn{6}{|c|}{ a. Dependent Variable: Job Performance } & & & \\
\hline
\end{tabular}

The above table shows the effects of career satisfaction on knowledge worker job performance. The results of the regression analysis indicate that career satisfaction $(p=.000)$ influence knowledge worker job performance. Hair et al., (2007) suggested that $p$ value should be less than $0.05(\mathrm{P}<0.05)$. Furthermore, the results of the regression analysis explain that career satisfaction explained $37 \%(\mathrm{R}$ square $=0.372)$ of the variance in knowledge workers job performance. 


\subsubsection{Mediating Role of Knowledge Management}

To know the mediating role of career satisfaction, we have performed the Sobel test suggested and developed by Sobel (1982), as many researchers have used this method to know the mediating role of the variables.

Table 6. Mediating role of career satisfaction between career values, perceived organizational support and knowledge worker job performance

\begin{tabular}{|l|l|}
\hline Variables & P-value \\
\hline Career Values & 0.011 \\
\hline Perceived Organizational Support & 0.007 \\
\hline
\end{tabular}

According to table 6 , the p-value of career values and perceived organizational support is less than the cut of point of 0.05 which indicate that career satisfaction mediate between the relationship between career values, POS and knowledge workers job performance.

\section{Findings}

Table 7. Hypothesis testing

\begin{tabular}{|l|l|l|}
\hline Hypothesis & P-Value & Accept/Reject \\
\hline There is positive relationship between career values and career satisfaction. & 0.006 & Accept \\
\hline $\begin{array}{l}\text { There is positive relationship between perceived organizational support and } \\
\text { career satisfaction. }\end{array}$ & 0.000 & Accept \\
\hline $\begin{array}{l}\text { There is positive relationship between career satisfaction and job } \\
\text { performance. }\end{array}$ & 0.000 & Accept \\
\hline
\end{tabular}

The above table explains the results of the hypotheses with p-value. The results of the analysis indicate that knowledge workers career values positively influence knowledge workers career satisfaction. The p-values is less than $0.05(\mathrm{P}=0.006$, Hair et al., 2006), which shows that the hypothesis should be accepted. Therefore, the result of the analysis supports H1.

The results of the analysis also indicate that perceived organizational support positively influence knowledge workers career satisfaction with p-value less than 0.05. Hair et al. (2006) suggested that P-value should be less than 0.05 in order to accept the hypothesis. Therefore, the results show that the relationship between perceived organizational support and knowledge workers career satisfaction is significant with $(\mathrm{P}=0.000$, Hair et al., 2006). Therefore, the results of the analysis support $\mathrm{H} 2$.

The results of the analysis also indicate that knowledge worker career satisfaction positively 
influence knowledge worker job performance with $p$ value less than 0.05 . Hair et al. (2006) suggested that P-value should be less than 0.05 in order to accept the hypothesis. Therefore, the results show that the relationship between knowledge worker career satisfaction and knowledge worker job performance is significant with ( $\mathrm{P}=0.000$, Hair et al., 2006). Therefore, the results of the analysis support $\mathrm{H} 3$.

Finally, the results of the analysis indicate that knowledge workers career values, perceived organizational support work together and positively influence knowledge worker career satisfaction, and knowledge worker career satisfaction further positively influences knowledge worker job performance with p-value of less than 0.05. It is in accordance with Hair et al. (2006) that p-values should be less than 0.05 in order to accept the hypothesis. Therefore, the result displayed in above table shows that knowledge worker career values and perceived organizational support work together and influence knowledge worker job performance through knowledge worker career satisfaction. $(\mathrm{P}<0.05, \mathrm{P}=0.000$, Hair et al., 2006). In other words, knowledge worker career satisfaction mediates the relationship between career values (effect $=0.011$ ), perceived organizational support (effect $=0.007$ ) and knowledge worker job performance. Therefore, the results of the analysis support H4.

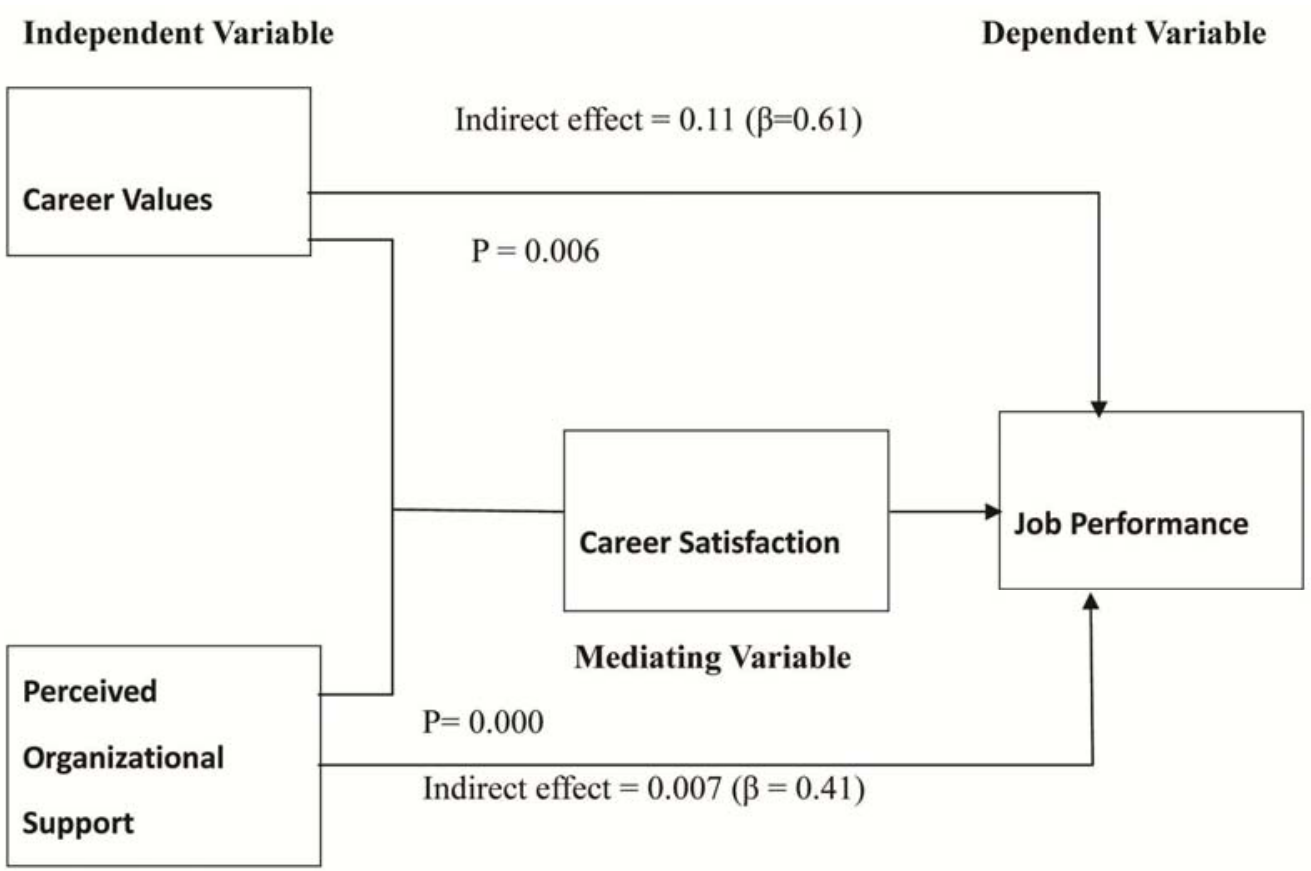

Figure 2. Research framework

As discussed earlier, the findings of the study explain that career satisfaction fully mediate the relationship between career values and knowledge worker job performance $(\beta=0.61)$. Furthermore, career values indirectly influence $($ effect $=0.011)$ knowledge worker job performance through career satisfaction. In other words, career satisfaction fully mediates the 
relationship between career values and knowledge worker job performance.

The findings of the study also explain that career satisfaction fully mediate the relationship between perceived organizational support and knowledge workers job performance $(\beta=0.41)$. Furthermore, perceived organizational support indirectly influence (effect $=0.007$ ) knowledge workers job performance through career satisfaction. In other words, career satisfaction fully mediates the relationship between perceived organizational support and knowledge worker job performance.

\section{Discussion}

The purpose of this study is to examine the role of career values, perceived organizational support in career satisfaction and job performance of knowledge workers. The findings of the study helped to answer five research questions developed in this research. Regarding research question 2: what is the effect of perceived organizational support on knowledge worker career satisfaction? The result of the study suggested that perceived organizational support helps knowledge workers to achieve career satisfaction and improve their job performance. The results of the study are consistent with Latif \& Sher (2012). The possible explanation of these findings might be the organization's contributions towards employee development. When an organization provides opportunities to the employees for development or provide facilities which are important in the eyes of employees, this could develop in the employees' mind that their organization are supportive. If the employees perceived that their organization will support them for personal and career development, it creates a sense of career satisfaction among employees, which further help the employees to better focus on their job and perform better at workplace. This practice become more critical when it comes to knowledge workers. Knowledge workers are usually more concerned about their personal and career development, and when they perceive organizational support, it helps them to achieve career satisfaction and improve job performance. In this regard, supervisor support works as an indicator to make knowledge workers realize organizational support. Normally, employees consider the supervisor to be a representative of top management and that supervisor support creates an impression in the employees mind that the organization cares about the employee's well-being and value the employee's effort and contributions to the organization. Supervisor support can generate a sense of career satisfaction among knowledge workers in many ways. Kalliah \& Beck (2001) argue that supervisor support helps knowledge workers improve job performance and reduce chances of burn out and turnover. Furthermore, Yoon \& Thye (2002) suggested that an increase in supervisor support develop employee perception about organizational support. In addition, recognition of the knowledge workers' efforts and contribution to the organization develop positive perceptions that the organization values their effort and that the organization is ready to handle any stressful situation and help knowledge workers to successfully perform their job. Therefore, perceived organizational support plays an important role toward career satisfaction and in improving job performance of knowledge workers.

The findings of the study explain that employees who are satisfied with their career in terms of pay, advancement, achievement of career goals, and development of new skills have the 
capacity to improve their job performance. The findings also suggested that retention of those employees who are highly satisfied with their career will help the organization improve performance through the employee's performance. The findings of this study support Judge et al. (2001) regarding satisfaction and performance in which they argue that satisfaction-performance correlation compares favorably with the other correlations of job performance and should not be dismissed in future empirical studies. Finally, the results of the study explain that perceived organizational support, career values influence knowledge worker job performance through career satisfaction. The findings of the study are consistent with Muse \& Stamper's (2007) and Bagozzi’s (1992).

\section{Implications}

This research hopes to serve two purposes: one, it is hoped that the research will contribute socially for the betterment of leadership in organizations, particularly in Saudi Arabian and two, the research will also contribute scientifically for future researchers to have a basis for further investigation on knowledge employees and their career success through career values and perceived organizational support. This study should help establish the role knowledge employees could play in shaping their own career in accordance to their career values and to achieve career satisfaction. The findings of the study explain that perceived organizational support create career satisfaction among knowledge workers and help them to improve job performance. Managers in Saudi Arabian organizations should take some initiative to develop the knowledge workers' perception about organizational support. Organizations should support their knowledge workers and this support can be through their supervisor, or through pay increase, appreciation and encouragement. Managers should appreciate the knowledge workers' good work and contribution on continued basis. Involving knowledge workers in decision making processes will send a strong massage to knowledge workers that their organization values their efforts and contributions. Furthermore, career planning will also help the managers satisfy the knowledge workers in terms of career progression. It should also contribute to creating awareness amongst managers and the roles organizations can play to motivate their knowledge workers and retain them by creating and sustaining organizational support for knowledge workers. Generally, this study will help minimize the gap between the employers and the employees in terms of conflict management (Chen 2010)

The study contributes to research relating to career development. $\mathrm{Ng}$ et al's (2005) meta-analysis summed, that at the moment, there are four types of predictors of career success; human capital, organizational sponsorship, socio-demographic status, and stable individual difference. Considering the fact that there are few researches on career values antecedents of career satisfaction, an important factor that this study explores is career values in relation to career success. It is rationalized that those employees who reported high levels of POS will attest to greater career success than their counterparts who do not.

\section{References}

Alavi, M., \& Leidner, D. E. (1999). Knowledge management systems: issues, challenges and benefits. Communications of the AIS, 1, 1-37. 
Alderfer, C. P. (1967). Convergent and Discriminant Validation of Satisfaction and Desire Measures by Interviews and Questionnaires. Journal of Applied Psychology, 51(6), 509-520. https://doi.org/10.1037/h0025101

Allen, D. R., Hitt, M., \& Greer, C. R. (1982). Occupational stress and perceived organizational effectiveness in formal groups: an examination of stress level and stress type. Personnel Psychology, 35(2), 359-371. https://doi.org/10.1111/j.1744-6570.1982.tb02201.x

Antoniou, A., Pharoah, P. D., \& Narod, S. et al. (2003). Average Risks of Breast and Ovarian Cancer Associated with BRCA1 or BRCA2 Mutations Detected in Case Series Unselected for Family History: A Combined Analysis of 22 Studies. Am J Human Genet, 72, 1117-1130. https://doi.org/10.1086/375033

Armstrong-Stassen, M., \& Ursel, N. D. (2009). Perceived organizational support, career satisfaction, and the retention of older workers. Journal of Occupational and Organizational Psychology, 82(1), 201-220. https://doi.org/10.1348/096317908X288838

Arnolds, C. A., \& Boshoff, C. (2000). Does Higher Remuneration Equal Higher Job Performance? An Empirical Assessment of the Need-Progression Proposition in Selected Need Theories. South African Journal of Business Management, 31(2), 53-64.

Aryees, S., Chay, Y. W., \& Chew, J. (1994). An investigation of the predictors and outcomes of career commitment in the three stages. Journal of Vocational Behavior, 44, 1-16. https://doi.org/10.1006/jvbe.1994.1001

Authur, M. B. (1994). The Boundary less career: A New Perspective for Organizational Inquiry. Journal of Organizational Behavior, 15, 295-306. https://doi.org/10.1002/job.4030150402

Ayesha, S. (2012). Investigating the Correlation between Knowledge Asset Management and Organizational Performance. 3rd International Conference on Business and Economic Research, pp. 1-2.

Babin, B., \& Boles, J. S. (1998). Employee behavior in a service environment: a model and test of potential differences between men and women. Journal of Marketing, 62(2), 77-91. https://doi.org/10.2307/1252162

Bagozzi, R. P. (1992). The self-regulation of attitudes, intentions, and behavior. Social Psychology Quarterly, 55(2), 178-204. https://doi.org/10.2307/2786945

Borman, W. C., \& Motowidlo, S. J. (1997). Task performance and contextual performance: the meaning for personnel selection research. Human Performance, 10(2), 99-109. https://doi.org/10.1207/s15327043hup1002_3

Bosch-Sijtsema, P. M., Virpi, R., \& Matti, V. (2009). Knowledge work productivity in distributed teams. Journal of Knowledge Management, 13(6), 533-546. https://doi.org/10.1108/13673270910997178

Bouranta, N., Chitiris, L., \& Paravantis, J. (2009). The relationship between internal 
andexternal service quality. International Journal of Contemporary Hospitality Management, 21(3), 275-293. https://doi.org/10.1108/09596110910948297

Brown, S. P., \& Thomas, L. (2002). A New Look at psychological Climate and Its Relationship to Job Involvement, Effort, and Performance. Journal of Applied Psychology, 81(August), 358-368.

Byrne, Z. S., \& Hochwarter, W. A. (2007). Perceived Organizational Support and Performance: Relationships across level of organizational cynicism. Journal of Managerial Psychology, 23(1), 54-72. https://doi.org/10.1108/02683940810849666

Cable, D. M., \& DeRue, D. S. (2002). The convergent and discriminant validity of subjective fit perceptions. Journal of Applied Psychology, 87(5), 875-884. https://doi.org/10.1037/0021-9010.87.5.875

Caroline, A., Vincent, R., \& Estelle, M. M. (2007). Perceived Organizational Support and Organizational Commitment: The moderating effect of locus of control and work autonomy. $\begin{array}{llr}\text { Journal of } \quad \text { Managerial } & \text { Psychology, } & \text { 22(5), }\end{array}$ https://doi.org/10.1108/02683940710757209

Chen, Y. (2011), Chinese Knowledge Employees' Career Values, Perceived Organizational Support and Career Satisfaction, Zhejiang Gongshang University, Hangzhou, China, Pub. Online pp. 274-280. [Online] Available: http://www.SciRP.org/journal/ib

Chen, Y. Y., \& Fang, W. (2008). The Moderating Effect of Impression Management on the Organizational Politics Performance Relationship. Journal of Business Ethics, 79(3), 263-277. https://doi.org/10.1007/s10551-007-9379-3

Davenport, T. H. (2005). Thinking for a Living: How to Get Better Performance and Results from Knowledge Workers. Boston: Harvard Business School Press.

Davenport, T. H., \& Prusak, L. (1998). Working Knowledge: How Organizations Manage What They Know. Boston: Harvard Business School Press. Donnelly, 2006.

De Coninck. (2010). The Effect of Organizational Justice, Perceived Organizational Support, and Perceived Super-visor Support on Marketing Employees' Level of Trust. Journal of Business Research, 63(12), 1349-1355. https://doi.org/10.1016/j.jbusres.2010.01.003

Deborah, A., O'Neil, D. B., \& Argun, S. (2004). Women's Career Types: Attributions of Satisfaction with Career Satisfaction. Career Development International, 9(5), 479-480. Emerald Group Publishing Limited.

Dreher, G. F., \& Ash, R. A. (1990). A Comparative Study of Mentoring among Men and Women in Managerial, Professional, and Technical Positions. Journal of Applied Psychology, 75(5), 539-546. https://doi.org/10.1037/0021-9010.75.5.539

Drucker. (1999). Knowledge-Worker Productivity: The Biggest Challenge. California Management Review, 41(2), 79-94. https://doi.org/10.2307/41165987

Edvinsson, L., \& Malone, M. (1997). Intellectual Capital: Realizing your Company's True 
Value by Finding its Hidden Brainpower. New York, NY: Harper Business.

Eisenberger, R., Huntington, R., Hutchison, S., \& Sowa, D. (1986).Perceived organizational $\begin{array}{lllll}\text { support. Journal of } \quad \text { Applied } & \text { Psychology, } & \text { 71, }\end{array}$ https://doi.org/10.1037/0021-9010.71.3.500

Farth, J., Dobbin, G., \& Cheng, B. (1991). Cultural relativity in action: a comparison of self-ratings made by Chinese and US workers. Personnel Psychology, 44, 129-147. https://doi.org/10.1111/j.1744-6570.1991.tb00693.x

Fisher, K., \& Fisher, M. D. (1998). The Distributed Mind-Achieving High Performance Through the Collective Intelligence of Knowledge Work Teams. Amacom, Sydney.

Greenhaus, J. H., Parasuraman, S., \& Wormley, W. M. (1990). Effects of race on organizational experiences, job performance evaluations, and career outcomes. Academy of Management Journal, 33(1), 64-86. https://doi.org/10.2307/256352

Guzzo, R. S., Noonan, K. A., \& Elron, E. (1994). Expatriate managers and psychological $\begin{array}{llll}\text { contract. Journal of Applied } & \text { Psychology, 79, }\end{array}$ https://doi.org/10.1037/0021-9010.79.4.617

Hair, J. F., Jr., Anderson, R. E., Tatham, R. L., \& Black, W. C. (1998). Multivariate Data Analysis (5th ed.). Upper Saddle River: Prentice Hall.

Han, G. H. (2010). Trust and Career Satisfaction: The role of LMX. Career Development International, 15(5), 437-458. https://doi.org/10.1108/13620431011075321

Hassan, I. B. (2007). Career Satisfaction: The effects of human capital, person-environment fit and organizational support. Journal of Managerial Psychology, 22(8), 741-765. https://doi.org/10.1108/02683940710837705

Horwitz, F., Heng, C. T., \& Quazi, H. A. (2003). Finders, keepers? Attracting, motivating and retaining knowledge workers. Human Resource Management Journal, 13(4), 23-44. https://doi.org/10.1111/j.1748-8583.2003.tb00103.x

Ilgen, D. R., \& Klein, H. J. (1988). Individual motivation and performance: cognitive influences on effort and choice. In A. R. Elangovan \& J. L. Xie (2000), Effects of perceived power of supervisor on subordinate work attitudes. Leadership \& Organization Development Journal, 21(6), 319-328.

Jackson, S. E. (2000). The IT employee-hanging on to the high-tech employee. Climate Magazine, 11(6).

Judge, T., Cable, D., Boudreau, J., \& Bretz, R. (1995). An empirical investigation of the predictors of executive career success. Personnel Psychology, 48(3), 485-519. https://doi.org/10.1111/j.1744-6570.1995.tb01767.x

Jurgensen. (1978). Job Preferences (What Makes a Job Good or Bad?). Journal of Psychological, 63(3), 267-276. https://doi.org/10.1037/0021-9010.63.3.267 
Kalleberg, A. (1977). Work Values and Job Rewards: A Theory of Job Satisfaction. American Sociological Review, 42(1), 124-143. https://doi.org/10.2307/2117735

Kalliah, T., \& Beck, A. (2001). Is the path to burnout and turnover paved by the lack of supervisory support: a structural equations test? New Zealand Journal of Psychology, 30, 72-78.

Khulida, K. Y., \& Tan, F. Y. (2011). Employee Personality and its Association to Insurance Agents' Career Satisfaction, Proceedings of the International Soft Science Conference, Ho Chi Minh, Vietnam, p. 2.

Kimberly, A. E. (2008). The Effect of Social Comparisons on Managerial Career Satisfaction and Turnover Intention. Career Development International, 14(1), 87-110.

Kimbu, A. N. (2011). The challenges of marketing tourism destinations in the Central African subregion: the Cameroon example. International Journal of Tourism Research, 13(4), 324-336. https://doi.org/10.1002/jtr.853

Kirchmeyer, C. (1998). Determinants of Managerial Career Success: Evidence and Explanation of Male/Female Differences. Journal of Management, 24(6), 673-692. https://doi.org/10.1177/014920639802400601

Kong, H., Cheung, C., \& Song, H. (2012). From hotel career management to employees' career satisfaction: the mediating effect of career competency. International Journal of Hospitality Management, 31(1), 76-85. https://doi.org/10.1016/j.ijhm.2011.03.002

Krieshok, T. S., Arnold, J. J., Kuperman, B. D., \& Schmitz, N. K. (1986). Articulation of Career Values: Comparison of Three Measures. Journal of Counseling Psychology, 33(4), 475-478. https://doi.org/10.1037/0022-0167.33.4.475

Larry, C. (1988). Comment on "Articulation of Values". Journal of Counseling Psychology, 35(2), 209-210. https://doi.org/10.1037/h0092542

Lee, O. F., Tan, J. A., \& Javalgi, R. (2010). International Journal Organizational Analysis, 18(1), 120-130. Emerald Group Publishing. https://doi.org/10.1108/19348831011033249

Litschka, M., Markom, A., \& Schunder, S. (2006). Measuring and analyzing intellectual assets: an integrative approach. Journal of Intellectual Capital, 7(2), 160-173. https://doi.org/10.1108/14691930610661836

Lock, G. (2003). Living, valuing and sharing - a case study of retaining IT professionals in the British Columbia public service. Career Development International, 8(3), 152-158. https://doi.org/10.1108/13620430310471069

Locke, E. A., \& Latham, G. P. (2002). Building a Practically Useful Theory of Goal Setting $\begin{array}{llll}\text { and Task Motivation. American Psychologist, } & \text { 57(9), }\end{array}$ https://doi.org/10.1037/0003-066X.57.9.705

Mintzberg, H. (1995). The professional organization. In H. Mintzberg, J. B. Quinn, \& S. Ghosal (Eds), The Strategy Process. London: Prentice Hall. 
Mitchell, R., \& Meacheam, D. (2011). Knowledge worker control: understanding via principle and agency theory. The Learning Organization, 18(2), 149-160. https://doi.org/10.1108/09696471111103740

Mohamed, M. S., O’Sullivan, K. J., \& Ribiere, V. (2008). A paradigm shift in the Arab region knowledge evolution. Journal of Knowledge Management, 12(5), 107-120. https://doi.org/10.1108/13673270810902975

Mottaz, C. J. (1986). An Analysis of the Relationship between Education and Organizational Commitment in a Variety of Occupational Groups. Journal of Vocational Behavior, 28(3), 214-228. https://doi.org/10.1016/0001-8791(86)90054-0

Muse, L. A., \& Stamper, C. L. (2007). Perceived organizational support: evidence for a mediated association with work performance. Journal of Managerial Issues, 19(4), 517-535.

Nair, N., \& Vohran, N. (2010). An exploration of factors predicting work alienation of knowledge workers. Management Decision, 48(4), 600-615. https://doi.org/10.1108/00251741011041373

Noe, R. A. (1996). Is Career Management Related to Employee Development and Performance? Journal of Organizational Behavior, 17(2), 119-133. https://doi.org/10.1002/(SICI)1099-1379(199603)17:2<119::AID-JOB736>3.0.CO;2-O

O’Donohue, W., Sheehan, C., Hecker, R., \& Holland, P. (2007). The psychological contact of knowledge workers. Journal of Knowledge Management, 11(2), 73-82. https://doi.org/10.1108/13673270710738924

O’Neill, B., \& Adya, M. (2007). Knowledge sharing and the psychological contract. Journal of Managerial Psychology, 22(4), 411-436. https://doi.org/10.1108/02683940710745969

Othman, M., Yunus, A. B., Shabudin, A., Rahman A., Rahim, N., \& Hamizah, H. (2012). Understanding Business People: Their Personality and Work Values Orientation. 3rd International Conference on Business and Economic Research, pp. 3070-3079.

Parasuraman, A., Zeithaml, V. A., \& Berry, L. L. (1996). SERVQUAL: A Multiple-item scale for measuring consumer perception of service quality. Journal of Retailing, 64(1), 12-40.

Podsakoff, P. M., MacKenzie, S. B., Lee, J. Y., \& Podsakoff, N. P. (2007). Common method biases in behavioral research: a critical review of the literature and recommended remedies. Journal of Applied Psychology, 88(5), 879-903. https://doi.org/10.1037/0021-9010.88.5.879

Rhoades, L., \& Eisenberger, R. (2002). Perceived organizational support: a review of the

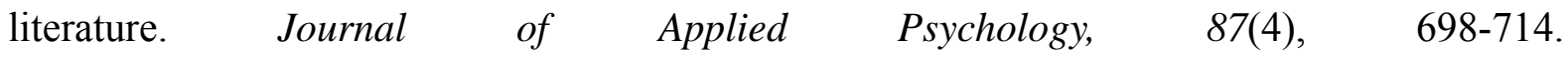
https://doi.org/10.1037/0021-9010.87.4.698

Scott, D., McMullen, T., \& Sperling, R. (2005). The fiscal management of compensation programs. World at Work Journal, 14(3), 13-25.

Seibert, S. E., \& Kraimer, M. L. (2001). Proactive Personality Indirectly Relates to Career Progression and Satisfaction through Specific Proactive Behaviors and Cognitive Processes. 
Personnel Psychology, 54, 845- 874. https://doi.org/10.1111/j.1744-6570.2001.tb00234.x

Sekaran. (2010). Paths to the job satisfaction of bank employees. Journal of Organizational Behavior, 10(4), 347-359. https://doi.org/10.1002/job.4030100405

Sergent, L. D., \& Domberger, S. R. (2007). Exploring the development of a protean career orientation: values and image violations. Career Development International, 12(6), 545-564. https://doi.org/10.1108/13620430710822010

Shapira, Z., \& Griffith, T. L. (1990). Comparing the Work Values of Engineers with Managers, Production, and Clerical Workers: A Multivariate Analysis. Journal of Organizational Behavior, 11(4), 281-292. https://doi.org/10.1002/job.4030110404

Spector, P. E. (1997). Job satisfaction: Application, assessment, causes, and consequences. London: Sage Publications.

Suazo, M. M., \& Turnhey, W. H. (2009). Perceived organizational support as a mediator of the relations between individual difference and psychological contract breach. Journal of Managerial Psychology, 25(6), 620-648. https://doi.org/10.1108/02683941011056969

Suliman, A. (2001). Work performance: is it one thing or many things? The multidimensionality of performance in a Middle Eastern context. International Journal of Human Resource Management, 12(6), 1049-1061. https://doi.org/10.1080/713769689

Sullivan, S. E., \& Baghat, R. S. (1992). Organizational stress, job satisfaction, and job performance: where do we go from here? Journal of Management, 18(2), 353-374. https://doi.org/10.1177/014920639201800207

Tan, F. Y., \& Khulida, K. Y. (2011). Personality Traits and Career Strategies as Determinants of Career Satisfaction. Journal Pengurusan, 33, 33-59.

Tan, F. Y., \& Khulida, K. Y. (2011). The Influence of Career Planning Towards Insurance Agents' Strategy for Career Satisfaction. Journal of Business and Policy Research, 6(2), 83-95.

Van Scotter, J. R., Motowidlo, S. J., \& Cross, T. C. (2000). Effects of task and contextual performance on systematic rewards. Journal of Applied Psychology, 85(4), 526-535. https://doi.org/10.1037/0021-9010.85.4.526

Vartiainen, M. (2007). Teams in globalised collaborative working environments and their coping mechanism. Globalization and New Collaborative Working Environments. Conceptual Framework incl. Review of State-of-the-art in Research and Practice, WP1 deliverable: D1.2, New Global, European Union Report, pp. 107-144.

Vroom, V. H. (1964). Work and Motivation. New York: Wiley, NY.

Watson, S., \& Hewett, K. (2006). A Multi-Theoretical Model of Knowledge Transfer in Organizations: Determinants of Knowledge Contribution and Knowledge Reuse. Journal of Management Studies, 43(2). https://doi.org/10.1111/j.1467-6486.2006.00586.x 


\section{Macrothink}

Business and Management Horizons

ISSN 2326-0297

2017, Vol. 5, No. 2

Wayne, S. J., Shore, L. M., \& Liden, R. C. (1997). Perceived organizational support and leader member exchange: a social exchange perspective. Academy of Management Journal, 40, 82-111. https://doi.org/10.2307/257021

Werner, J. M. (2000). Implications of OCB and contextual performance for human resource management. Human Resource Management Review, 10(1), 3-24. https://doi.org/10.1016/S1053-4822(99)00036-4

Werner, J. M., \& De Simone, R. L. (2006). Human Resource Development (4th edition). Ohio: Thomson South-Western.

Yavas, U., Karatepe, O. M., \& Babakus, E. (2010). Relative efficacy of organizational support and personality traits in predicting service recovery and job performances: a study of frontline employees in Turkey. Tourism Review, 65(3), 70-83. https://doi.org/10.1108/16605371011083530

Yerkes, R. M., \& Dodson, J. D. (1908). The Relationship of Strength of Stimulus to Rapidity of Habit Formation. Journal of Comparative Neurology and Psychology, 18, 459-482. https://doi.org/10.1002/cne.920180503

Yigitcanlar, T., Baum, S., \& Horton, S. (2007). Attracting and retaining knowledge workers in knowledge cities. Journal of Knowledge Management, 11(5), 6-17. https://doi.org/10.1108/13673270710819762

Yoon, J., \& Thye, S. (2002). A dual process model of organizational commitment. Work and Occupations, 29(1), 97-124. https://doi.org/10.1177/0730888402029001005

Yousef, D. A. (1998). Satisfaction with job security as a predictor of organizational commitment and job performance in a multicultural environment. International Journal of Manpower, 19(3), 184-194. https://doi.org/10.1108/01437729810216694

Yu, C. (2010). Career Satisfaction of Knowledge Workers: The Effects of Perceived Organizational Support and Person-Job Fit (pp. 390-394). [Online] Available: http//www.scirp.org/journal/ib

\section{Copyright Disclaimer}

Copyright for this article is retained by the author(s), with first publication rights granted to the journal.

This is an open-access article distributed under the terms and conditions of the Creative Commons Attribution license (http://creativecommons.org/licenses/by/3.0/). 